\title{
Re-Thinking Reciprocity: A New Framework for WTO Disciplines on North-South Regional Trade Agreements
}

\author{
Lorand Bartels / Sacha Silva / Hadil Hijazi / Hannes Schloemann / Thomas Cottier
}

Abstract

The Economic Partnership Agreement (EPA) negotiations between the European Union and its African, Caribbean and Pacific (ACP) partners represent the most significant free trade agreement negotiations between developed and developing countries to date, and hold valuable lessons for the ongoing review of WTO rules on development aspects of regional trade agreements. These negotiations, which have proceeded on the basis of existing WTO rules, serve neither trade nor development objectives. The central reason for this is that existing WTO rules - principally Article XXIV GATT - have a 'tariff bias' in which only liberalization in goods is taken into account in determining the legality of a regional trade agreement. Based on an analysis of the development and trade issues in the EPA negotiation process, this paper proposes a new view of measuring RTA liberalization in which account is also taken of a broader set of economic interests - including services, aid-for-trade and trade facilitation. This paper also demonstrates that such an understanding of regional trade liberalization does not conflict with the original purpose of Article XXIV, even if there is a need for some reform of this provision to bring it up to date. The paper concludes with a series of legal options that reflect this outcome, ranging from a reinterpretation of existing RTA disciplines to formal reform.

Keywords: Regional trade agreements, free trade agreements, developing countries, Economic Partnership Agreements, EU-ACP trade relations, tariff negotiations, Article XXIV GATT.

NCCR TRADE WORKING PAPERS are preliminary documents posted on the NCCR Trade Regulation website (<www.nccr-trade.org $>$ ) and widely circulated to stimulate discussion and critical comment. These papers have not been formally edited. Citations should refer to an "NCCR Trade Working Paper", with appropriate reference made to the author(s).

\section{FNSWF}

FONDS NATIONAL SUISSE SCHWEIZERISCHER NATIONALFONDS FONDO NAZIONALE SVIZZERO
Die Nationalen Forschungsschwerpunkte (NFS) sind ein Förderinstrument des Schweizerischen Nationalfonds. Les Pôles de recherche nationaux (PRN) sont un instrument d'encouragement du Fonds national suisse.

The National Centres of Competence in Research (NCCR) are a research instrument of the Swiss National Science Fondation. 


\title{
Re-Thinking Reciprocity: A New Framework for WTO Disciplines on North-South Regional Trade Agreements*
}

\author{
Lorand Bartels ${ }^{1}$ \\ Sacha Silva \\ Hadil Hijazi \\ Hannes Schloemann ${ }^{2}$ \\ Thomas Cottier ${ }^{3}$
}

\begin{tabular}{|c|}
\hline Table of Contents \\
\hline 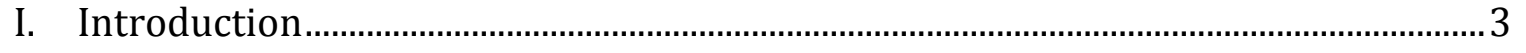 \\
\hline II. The "Trade and Development" RTA: A New Archetype ….................................. \\
\hline III. What Does "WTO Compatibility" Mean? …………… \\
\hline 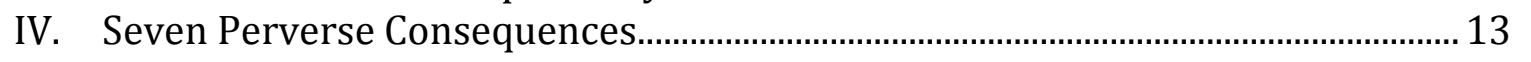 \\
\hline 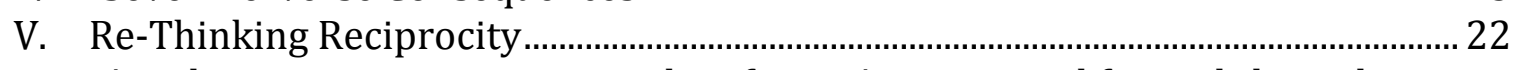 \\
\hline $\begin{array}{l}\text { VI. Article XXIV as a Positive Discipline for RTA Parties and for Multilateralism } \\
\text { Error! Bookmark not defined. }\end{array}$ \\
\hline 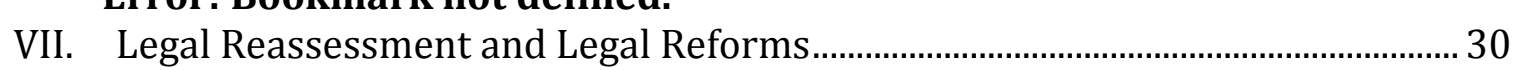 \\
\hline VIII. Conclusions \\
\hline 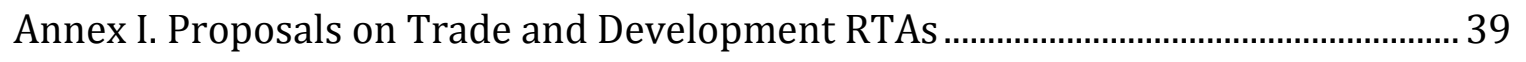 \\
\hline
\end{tabular}

\footnotetext{
* This paper represents research conducted as part of the NCCR Trade Regulation's Work Package 2 (www.nccr-trade.org). Funding through the NCCR is gratefully acknowledged.

1 University Senior Lecturer in Law and Fellow of Trinity Hall, University of Cambridge (lab53@cam.ac.uk)

2 Senior Economist, WTI Advisors (sacha.silva@wtiadvisors.com); Director, WTI Advisors (hadil.hijazi@wtiadvisors.com); and Director,WTI Advisors (hannes.schloemann@wtiadvisors.com).

3 Professor of European and International Economic Law, University of Berne; and Managing Director, World Trade Institute (thomas.cottier@wti.org).
} 


\section{Introduction}

In November 2001, the Doha WTO Ministerial Conference mandated Members to review multilateral disciplines on regional trade agreements (RTAs) to "take into account the developmental aspects of regional trade negotiations". At around the same time, the European Union and the 79 members of the African, Caribbean and Pacific (ACP) Group launched negotiations for WTO compatible Economic Partnership Agreements (EPAs). These were intended to be WTO compatible free trade agreements that would replace the system of WTO-inconsistent unilateral preferences granted by the EU to the ACP countries under the Lomé Conventions and the Cotonou Agreement. But they were also intended to be a new type of NorthSouth regional trade agreement: one with the conscious objective of favouring development. The difficult question is how far this is possible, given the constraints of the unreformed WTO disciplines on regional trade agreements.

In this paper, the authors - all of whom have been closely involved in assisting ACP countries in the EPA process - argue that current RTA disciplines, particularly Article XXIV GATT, serve neither development nor trade needs. Based on analysis of the process and results of the EPA negotiations, this paper demonstrates how a need to produce a WTO-compatible free trade agreements has led negotiators to focus almost exclusively on the "substantially all the trade" criterion in Article XXIV and hence on tariffs on goods. However, as this paper shows, this focus does not make sense either in terms of development, because it ignores the real interests of the developing country partners, nor from an economic perspective, in part for the same reason, but also because this focus ignores the multilateral benefits of regional trade liberalization. Thus Article XXIV GATT, as currently understood, creates a system of perverse incentives that benefit neither the parties to the agreement, nor, when seen from a proper perspective, third party WTO Members.

The paper suggests a way to remedy these perverse incentives by broadening the WTO framework for North-South RTA disciplines beyond a singular focus on Article XXIV. Building on earlier criticisms of Article XXIV ${ }^{4}$ and recent work on the multilateral effects of modern regional trade agreements, ${ }^{5}$ it proposes a framework that allows for concessions in all areas of RTA negotiation to be taken into account when assessing whether or not an RTA (or the preferences it entails) should be tolerated by the otherwise MFN-based WTO system. Within this framework, RTA partners would be able to trade off concessions not only within the classical pillars of the multilateral trading system - e.g. market access in goods and services - but between these pillars, as well as all other, including newer and upcoming areas of

\footnotetext{
${ }^{4}$ Eg McMillan (1993). 'Does Regional Integration Foster Open Trade? Economic Theory and GATT's Article XXIV'. For a detailed legal discussion, see Mathis (2002). Regional Trade Agreements in the GATT/WTO: Article XXIV and the Internal Trade Requirement.

${ }^{5}$ Baldwin (2011). See also WTO (2011), World Trade Report 2011, The WTO and Preferential Trade Agreements: From Co-existence to Coherence, at 168-171.
} 
WTO law and related negotiations (e.g. trade facilitation, SPS, TBT, Aid-for-Trade) as well. The paper proposes a new understanding, in place of the current restrictive view of reciprocity but in line with its underlying rationale that will encourage the achievement of a liberalization package that serves the interests both of the negotiation parties and of third country WTO Members.

The proposals in this paper comprise three main elements: first, and fundamentally, a reorientation of the 'substantially all the trade' requirement in Article XXIV:8 GATT; second, the need for purpose-oriented procedural disciplines on liberalization rather than reliance on invariably unwieldy quantifications; third, an open-minded approach to quantification of both (1) liberalization in other sectors, including but not limited to services, and (2) the multilateral benefits of the agreement, including those stemming from regional integration. The paper argues that such a cross-sectoral widening of WTO Members' view of reciprocity would create substantial multilateral benefits and more meaningfully contribute to the goal of trade liberalization (particularly in the North-South context), thus ensuring that the rules on regional trade agreements encourage the type of agreements that are positive for development and for other WTO Members, that reflect the concerns of the twenty-first century, and that are, fundamentally, a better, more accurate reflection of the object and purpose of RTA disciplines than the traditional approach.

Section II outlines the challenges involved in creating a new "trade and development" RTA archetype embodied by the EPA. Section III outlines the challenge of ensuring the WTO compatibility of that new archetype. Section IV examines the consequences, in the EPA setting, of the conflict between the new RTA approach and traditional WTO disciplines. Section V outlines the proposal of rethinking the notion of reciprocity in the context of RTA disciplines to encompass all aspects of trade and trade regulation, and hence allow for broader trade-offs in line with the logic and interest of the WTO system. Section VI reflects on the need to understand Article XXIV GATT as a positive discipline in the sense that it is meant to generate, and should be interpreted to generate, multilateral benefits. Section VII explores the legal avenues through which the needed re-calibration of current RTA disciplines could be achieved. Section VIII concludes.

\section{The "Trade and Development" RTA: A New Archetype}

The EPA negotiations were, crucially, prompted by the fact that WTO Members were running out of patience with the European Union's system of unilateral preferences for the ACP, covered by successive waivers from Article I GATT, the major battles being fought about the EU's tariff preferences for ACP banana. But notwithstanding the EU's and the ACP's motivation to conform ACP preferences to WTO disciplines, both sides also aimed to create a new kind of North-South RTA: one whose provisions explicitly favoured the developing country partner(s). The rhetoric and vision of a new "trade and development" archetype was built on a cooperation 
model that the EU and the ACP are intimately familiar with, building on a long history of cooperation under the various Lomé Conventions and the 2000 Cotonou Agreement; a model that was meant to find it fullest WTO-compatible expression in the EPA. This new archetype drew on four key elements, each of which will be considered in turn.

\section{Qualitative, Not Quantitative}

The first key element of the trade and development RTA is its supplanting of the traditional drivers of trade negotiations with policy objectives drawn from the aid and development debates. It is instructive to begin with the objectives of more traditional North-South RTAs. For example, in the ASEAN-Australia-New Zealand Closer Economic Partnership Agreement, the objectives of the agreement, as stated in its preamble, are

to minimise barriers and deepen and widen economic linkages among the Parties; lower business costs; increase trade and investment; enhance economic efficiency; create a larger market with more opportunities and greater economies of scale for business[.] ${ }^{6}$

The choice of wording favours traditional, often explicitly measurable economic indicators - business costs, efficiency, markets, scale and investment. The implicit assumption - here in the context of an agreement that includes three UN-designated LDCs - is the classic argument that trade liberalization will in itself foster the goals of the agreement, including economic development.

The contrast with the EPA is stark. The objectives of the EPA, as stated in the Cotonou Agreement, are that the agreements are meant to:

foster... the smooth and gradual integration of the ACP States into the world economy, with due regard for their political choices and development priorities, thereby promoting their sustainable development and contributing to poverty eradication in the ACP countries[,] enable the ACP States to play a full part in international trade [and] manage the challenges of globalisation and to adapt progressively to new conditions of international trade thereby facilitating their transition to the liberalized global economy. ${ }^{7}$

The choice of policy goals - e.g. "political choice", "integration", "challenges of globalization" and "sustainable" - are distinct from the traditional RTA aims noted above; more importantly, they are generally qualitative aims for which precise indicators have yet to be agreed on or developed. ${ }^{8}$ The EPAs of course are not

6 Australia/NZ-ASEAN Free Trade Agreement, preamble, full text available online at https://www.dfat.gov.au/fta/aanzfta/contents.html.

${ }^{7}$ Article 34 of the Cotonou Agreement. Many of these objectives are now also enshrined as objectives of the EU's development policies in Article 21 of the Treaty on European Union, and Article 208 of the Treaty on the Functioning of the European Union.

${ }^{8}$ For an example of the challenges of creating indicators of regional integration, and the difficulty in comparing different estimates, see "Monitoring regional integration in the ACP: The case for a coordinated approach", Trade Negotiating Insights, Vol 8:9, International Centre for Trade and Sustainable Development, Geneva, November 2009. 
wholly unique in mentioning some of these goals, ${ }^{9}$ but most would agree that these more qualitative aims are usually not at the forefront of trade negotiators' thinking, nor explicit in their mandates: here the EPA was, and remains, a fundamentally different exercise.

\section{Beyond Traditional Market Access}

The second key pillar of the trade and development RTA is the widening of the trade negotiating agenda from the classical first pillar of the multilateral trading system (that is, market access in goods) to a broader focus that links the wider, post-1994 WTO agenda - services, SPS, TBT, trade facilitation, Aid-for-Trade and others - into a comprehensive, single undertaking-style package. Once again, the trade and development concept is not unique in including these newer areas of the WTO on the negotiating agenda, but the emphasis placed on the potential development impact of these non-market access areas makes the EPA exercise stand out.

On one hand, there is a specific effort to de-emphasize any real commercial interests of the developed country partner. For example, as the negotiating rounds began in 2005, Peter Mandelson (then EU Trade Commissioner) stated that:

The ACP won't be asked to match this offer [of duty-free, quota-free access], and the tariff reductions they do offer will be subject to the flexibility provided by WTO rules which means the right to protect sensitive markets and use long transition times for change. I often hear claims that the EU is looking out only for its own commercial interests with EPAs. But Europe trades very little with ACP countries - we don't have offensive commercial interests in these negotiations. ${ }^{10}$

The direct experience of the authors and personal communications with ACP negotiators indicate that in most regions, this lack of emphasis on traditional commercial/market access considerations was faithfully adhered to - the EU did not press for market access in specific goods sectors, ${ }^{11}$ directing the ACP instead to

9 The Preamble to the Australia/NZ-ASEAN FTA quoted above continues to note that the parties are "CONFIDENT that this Agreement establishing an ASEAN-Australia-New Zealand Free Trade Area will strengthen economic partnerships, serve as an important building block towards regional economic integration and support sustainable economic development".

10 "Economic Partnership Agreements: Tackling the Myths - Comment by Peter Mandelson", European Commission, published in The Standard, Kenya, 23 April 2007. The DG Trade online factsheet (http://ec.europa.eu/trade/wider-agenda/development/economic-partnerships) also makes only a single (and noticeably indirect) reference to the potential benefits of the EPAs for EU firms - that "in the long run, trade will help ACP countries become more prosperous... in turn, that will generate more demand for European products and expertise, which will be good for employment."

11 Exceptions to the EU's non-offensive stance occurred when an ACP country had made prior commitments to a major developed economy (e.g. the DR's commitments to the US under DRCAFTA). This exception was later enshrined for future ACP RTAs in the EPA "MFN Clause". The EU, however, was not entirely without specific commercial interests in the negotiations. One point of note was (and is) the issue of export taxes. Here the EU has made every effort to obtain commitments for their elimination, in line with the EU's global raw materials initiative aimed at securing the supply of raw materials for EU producers and consumers. 
ensure that liberalization targets reached certain percentage thresholds for goods: a directive that, this paper will argue in Section IV, had fateful consequences.

On the other hand, there is an explicit focus on non-traditional areas of negotiation: the DG Trade online factsheet on the EPAs explicitly states that the agreements "go beyond conventional free-trade agreements ... focusing on ACP development". ${ }^{12}$ The EPA's emphasis away from traditional goods sectors and towards newer areas of trade is based on several considerations. First, there is the reality that most ACP countries have weak and/or undiversified goods production and small markets unlikely to be of great interest to most EU firms. Second, there is the realization that the traditional market-access based approach of the Lomé and Cotonou frameworks, in the absence of other trade-related measures, failed to produce the desired development results in the ACP, ${ }^{13}$ and that the true "development dimension" of trade negotiations can be harvested through system reforms (e.g. stronger Customs procedures through trade facilitation investments), large-scale investments (e.g. renovating port facilities with Aid-for-Trade funds) or attracting investments that spur the growth of new or "niche" export sectors (e.g. attracting FDI in facilities to train nurses for medical services delivery under "Mode 4").

This wider vision, apart from focusing attention away from traditional commodity sectors, also speaks to the very rationale for the creation of the WTO - the recognition that trade involves much more than just simple tariff reductions and/or a focus on goods trade. Six decades of evolution have delivered a multilateral trading system that encompasses a range of disciplines, including many "behind the border" issues of major relevance to cross-border economic relations. Furthermore, the reality of business practice in the $21^{\text {st }}$ century - e.g. through the use of ever more sophisticated and integrated global value chains - is reinforcing the economic linkages between key elements of the post-GATT agenda.

\section{Non-Commercial Configurations}

The third key pillar/innovation of the trade and development RTA is its use of negotiating configurations (i.e. individual countries grouped together for the purposes of the negotiations) whose actual mutual commercial interests or links are often marginal, or in some cases non-existent. In the EPA, ACP countries were grouped together based on geographical contiguity or historical/political affiliation, rather than by the strength of their trading relationship. For example, the actual economic orientations of the Pacific Islands vary between the United States, Asia,

\footnotetext{
12 Available online at http://ec.europa.eu/trade/wider-agenda/development/economicpartnerships.

${ }^{13}$ As the DG Trade factsheet notes, "for well over 30 years, exports from the ACP countries were given generous access to the European market... yet preferential access failed to boost local economies and stimulate growth in ACP countries... and the proportion of EU imports from ACP countries dropped from $7 \%$ to $3 \%$ of EU imports."
} 
Australia and New Zealand, with minimal intra-regional trade. ${ }^{14}$ In the case of Cariforum, most countries by a large margin depend on trade with the United States and Latin America; intra-regional trade in most cases is confined to a very narrow set of goods, such as the export of petroleum products and some processed foods/beverages from Trinidad, ${ }^{15}$ apart from small-scale trade in niche products. Similarly, the links across the EPA negotiating table are increasingly weak. Few ACP countries (particularly outside of Africa) count the EU as their major trading partner, apart from a few key export sectors in individual countries such as sugar and fish in Fiji and Papua New Guinea, cocoa in West Africa, horticulture in East Africa, sugar and bananas in the Caribbean, and energy/mining interests throughout the ACP. For other countries however - and the ACP as a whole on the import side traditional imports from the EU either have been or are increasingly being supplanted by lower-cost partners in Asia, Latin America or North America. ${ }^{16}$

\section{Negotiating With SVEs and LDCS}

The fourth major innovation of the trade and development archetype, building on the use of non-commercial configurations listed above, is the encouragement of the participation of SVEs and LDCs in ambitious (in scope at least) RTA negotiations. This encouragement is given despite many SVEs' and LDCs' well-documented caution regarding the feasibility of realising development benefits through classical assumptions of trade liberalization. ${ }^{17}$ This caution is grounded in a link between the economic profile of SVEs and LDCs - their small and often monopolistic domestic markets, narrow export base, high border tax dependence, remote location and vulnerability to natural disasters - and their low share of global trade, relative lack of decision-making power within many multilateral forums, dependence on aid flows and lack of interest by major powers in their small consumer markets.

Historically, the primary motivation for SVEs and LDCs to engage in multilateral negotiations - particularly with much stronger partners such as the EU - has been to

\footnotetext{
${ }^{14}$ See "Assessment of the Extent of Trade Liberalisation in Pacific Island Countries (PICs) and Review of the Pacific Island Countries Trade Agreement (PICTA)", Robert Scollay, Report prepared for the Pacific Islands Forum Secretariat, September 2008.

15 See "CARICOM: Challenges and Opportunities for Caribbean Economic Integration", Congressional Research Service, January 2008.

${ }^{16}$ For an analysis of the African context, see "Europe: less important to Africa than you might think", Financial Times "beyondbrics" blog, 2 November 2012, accessed online at http://blogs.ft.com/beyond-brics/2012/11/02/europe-less-important-to-africa-than-you-mightthink.

17 See Grynberg (2006), WTO At the Margins: Small States and the Multilateral Trading System, Cambridge University Press; Grynberg and Razzaque (2004), The Trade Performance of Small States, Commonwealth Secretariat, London; Bernal (2001), "Small Developing Economies in the World Trade Organization", Paper Presented at the World Bank Conference on "Leveraging Trade, Global Market Integration and the New WTO Negotiations for Development," Washington, DC, July 23-24, 2001; and Wignaraja et al (2004), Small States in Transition: From Vulnerability to Competitiveness, Commonwealth Secretariat, London.
} 
preserve preferential margins for key export products to compensate for their economic handicaps, or to secure trade-related aid packages. The actual margin of preference has however eroded with time due to dispute settlement or bilateral/sectoral agreements with non-ACP countries. Thus trade negotiations are seen as a bitter zero-sum pill to be swallowed in exchange for the possibility of higher aid flows, or as the economic price to pay for maintaining a historical/political relationship in good standing, or simply a net loss of revenue or domestic production. As a result, in many SVE and LDC capitals, the window of political opportunity for (and attention to) trade matters is often noticeably short, with many other items (such as budget/fiscal issues, security and immigration) taking up much of the agenda space for an ACP country's Cabinet or Parliament.

The encouragement for SVE and LDC participation in the trade and development exercise is grounded in the post-GATT nature of the archetype: the trade and development RTA is precisely attractive to SVEs and LDCs because of its deemphasis on areas of perceived weaknesses (that is, goods trade where distances and infrastructure costs can weigh more heavily). The emphasis instead is placed on newer areas of trade that can either play to SVE and LDC strengths (e.g. tourism, culture), or promise larger systemic benefits beyond the narrow clique of manufacturing interests that have traditionally dominated ACP political life. The attraction is particularly strong for those few SVE and LDC countries that are not yet WTO Members, as the trade and development RTA provides an opportunity to test the waters of the different areas of the WTO work programme before formally becoming a full-fledged participant in multilateral negotiations.

\section{What Does “WTO Compatibility” Mean?}

\section{A Lively Debate Over RTAs and S\&D...}

The previous section outlined one half of the difficult balancing act facing ACP negotiators: the crafting of an innovative trade and development RTA model. The second half of the task - arguably just as complex as the first - was to square the innovations of the trade and development model with the circle of RTA disciplines within the WTO, namely Article XXIV GATT and Article V GATS. ${ }^{18}$

The fundamental basis of the debate over development, the WTO and RTAs was a range of proposals (submitted both within and outside the WTO), summarized in Annex I, each addressing the key question of how elements of S\&D could be afforded in favour of developing countries in RTA negotiations. The proposals related to, inter alia, systemic issues - the definition and calculation of coverage (e.g. "substantially all" trade), the length of transition periods, the definition of key terms

18 The third major RTA discipline, the Enabling Clause, is reserved for South-South RTAs only. 
(e.g. "restrictive regulations of commerce"), and the relationship between WTO disciplines and the Enabling Clause) - as well as procedural issues, including transparency and the notification of RTAs.

These proposals, in turn, fed a number of impact assessments that were prepared by the EU, the ACP and third parties, all in an attempt to estimate a priori the potential effects of the EPAs. ${ }^{19}$ Much like the proposals on development-friendly RTA disciplines listed in Annex I, these impact assessments were in most cases prepared before negotiations had begun, and thus the analysis was speculative, as there had been no agreement on final schedules of concessions. The impact studies fed a parallel discussion in press and NGO campaigns - both within the EU and the ACP over the potential impact of the EPA, particularly on the economies of the ACP countries, and were arguably influential in shaping the views of ACP trade stakeholders during the negotiations. ${ }^{20}$

\section{... But a Narrow Debate}

The EPA negotiations covered virtually the entire spectrum of WTO negotiations. The debate over WTO compatibility of North-South RTAs however in practice ignored much of this diversity. In the case of the EPA impact studies and the press/NGO debate in particular, the debate almost exclusively focused on WTO compatibility defined in increasingly narrow terms: goods trade, Article XXIV, and in particular the requirement to liberalize "substantially all" trade (hereinafter

\footnotetext{
19 See, as examples of the numerous impact studies prepared prior to the conclusion of the negotiations: Fontagné et al (2008), "An Impact Study of the EU-ACP Economic Partnership Agreements (EPAs) in the Six ACP Regions", Centre d'Études Prospectives et d'Information Internationales, Paris, April 2008; Brenton et al (2007), "Evaluating the Revenue Effects of Trade Policy Options for COMESA Countries: the Impacts of a Customs Union and an EPA with the European Union" The World Bank, April 2007; Busse et al (2004), "The Impact of ACP/EU Economic Partnership Agreements on ECOWAS Countries: An Empirical Analysis of the Trade and Budget Effects", Hamburg Institute of International Economics; Karingi et al (2005), "Economic and welfare impacts of the EU-Africa Economic Partnership Agreements", Africa Trade Policy Centre, Economic Commission for Africa, Addis; Keck and Piermartini (2008), "The Impact of Economic Partnership Agreements in Countries of the Southern African Development Community", Journal of African Economies, 17(1), 85; Milner et al (2005), "Some Simple Analytics of the Trade and Welfare Effects of Economic Partnership Agreements", Journal of African Economies, 14(3), 327-358; Ndlela \& Tekere (2003), "Impact Assessment of Economic Partnership Agreements on Southern African Development Community and Preliminary Adjustment Scenarios", Trade and Development Studies Centre: Harare, Zimbabwe; and Scollay (2002), "Impact Assessment of Possible Economic Partnership Agreements With the EU", Report for ACP Secretariat and the ACP Pacific States.

${ }^{20}$ See, as examples of the large numbers of press and NGO articles focused on the tariff aspects of the EPA: "Pace of ACP liberalisation, EPA negotiations too fast", IPS, Paris, January 2008; "Dangers of the EPA and Alternatives for Africa", South Bulletin Issue 60, South Centre, Geneva, April 2012; "Contentious issues in the interim EPAs: Potential flexibility in the negotiations", ECDPM Discussion Paper no. 89, European Centre for Development Policy Management, Maastricht, March 2009; "Unequal Partners: How EU-ACP Economic Partnership Agreements (EPAs) could harm the development prospects of many of the world's poorest countries", OXFAM Briefing Note, OXFAM International, September 2006.
} 
referred to as "SAT") within a "reasonable" period of time. The debate was especially strong given that the precise interpretation of SAT has remained contentious and thus ultimately unresolved, with contributions largely limited to speculating on what thresholds or transition could prove politically palatable to the wider WTO membership. ${ }^{21}$

This focus on goods however excluded the rest of the WTO agenda: while other WTO-RTA-development links were discussed by some authors - e.g. developmentfriendly benchmarks for services liberalization, or even other disciplines within Article XXIV outside of the SAT requirement - they failed to excite the same level of debate, analysis or contention. The debate over WTO compatibility in practice was reduced to a narrow debate over percentages relating to goods, crowding out even the other trade elements of the negotiating agenda.

The singular focus on tariff reduction was reflected in the perceptions and negotiating schedule of the ACP. Interviews conducted with members of the EPA teams in the Caribbean, Pacific and Africa for this paper indicate that the achievement of a specific percentage-of-trade SAT threshold was the "primary" consideration with respect to WTO compatibility of the EPA - not only for the WTO compatibility of the goods schedules (where a focus on Article XXIV would be understandable), but for the entire EPA package which, as noted earlier, sought to cover virtually all WTO negotiating areas. The focus on tariffs resulted in a lopsided amount of time allotted to negotiating tariff concessions, and this despite the EU's status as a minor trading partner in goods for most of the ACP. For example, in the case of the CARIFORUM countries, fourteen regional Technical Working Groups and fifteen EC-CARIFORUM Technical Negotiating Group sessions were required to agree on a final tariff liberalization schedule; fewer sessions were required for negotiating market access in services, a sector where the Caribbean has a global brand and significant European interests.

\section{Tariffs and the Fear of the Unknown}

The bias towards focusing on tariff reductions, at the expense of virtually all other areas of the trade and development agenda, had and has powerful roots in the legal status quo as it was understood and perceived by the negotiating partners. One element, one which will form the basis of the policy conclusions of this paper, is the fact that there are only two disciplines within the WTO that apply to RTAs - Article XXIV GATT and Article V GATS. The latter standard for services agreement is routinely violated, or at least stretched, in practice (particularly with respect to the coverage of Mode IV commitments), and thus is arguably not perceived as setting as high a standard as that set for goods in Article XXIV GATT. ${ }^{22}$ Thus a goods-only focus

${ }^{21}$ Grynberg and Scollay (2005).

22 See "Services in Regional Trading Arrangements", in The World Trade Organization: Legal, Economic, and Political Analysis, Findlay et al (eds), Springer, 2005, p. 303. 
of WTO compatibility follows the same limited logic adopted by the Ministers at Doha - i.e. remaining within the box of the existing WTO disciplines on RTAs, implicitly condoning a status quo where no other RTA disciplines exist for the many new non-GATT/GATS areas of negotiations.

Another element was the origins of the EPA negotiations themselves. The very impetus for the negotiations grew out of the goods sector (that is, the litigation surrounding the EU's tariff preferences for the ACP), and the 1 January 2008 deadline for the completion of the negotiations was based on the expiry of the 2001 waiver that covered the trade in goods provisions of the Cotonou Agreement. Thus the proverbial Sword of Damocles hanging over the final EPA text was rooted in a legal challenge on compliance with the GATT, implying that negotiators were particularly sensitive of and acutely aware of the need for compliance with the GATT's own disciplines related to RTAs (i.e. Article XXIV).

The natural inclination towards a goods focus within the multilateral trading system, even for a North-South context where trade in goods may not constitute a major commercial interest, is even more deeply rooted in the history of global trade negotiations. The multilateral trading system was originally shaped in 1947 around encouraging and protecting tariff concessions, and tariff reduction is often the first substantive area of commitments addressed in the text of virtually all RTAs that involve tariff negotiations. The full inclusion of non-goods and non-tariff areas (e.g. services, investment) has been a gradual process, largely initiated by the Uruguay Round in 1986 that brought these new areas into the everyday work of the WTO negotiating committees.

This gradual process is even more magnified at the level of the WTO Members, particularly its smallest and least-developed constituents. Within the civil service, it is often goods-related ministries or departments (e.g. Customs, Agriculture, Finance and Commerce) that have the most experience and institutional memory of dealing with trade matters. Other non-goods Ministries (e.g. Education, Immigration, and Social Development) are both far less likely to see their activities from a trade perspective - despite the reality that WTO negotiations may create commitments in their areas of work - and less likely to be heard at the political level during a trade negotiation. ${ }^{23}$ This natural inclination towards goods is even more evident outside of the public sector. Only recently - in the ACP case, largely prompted by the EPA negotiations - have many developing countries sought to create negotiating coalitions in non-goods areas (such as private sector services coalitions) or publicprivate working groups on trade negotiations that have reached outside of the usual goods stakeholders.

${ }^{23}$ Even traditional chambers of commerce, which act as umbrella voices for the private sector, are traditionally dominated by manufacturers in many developing countries. See "The private sector and services development - the concept of 'service coalitions'", David Primack, presenting to "Positioning Services Reforms and Negotiations for Development", 14-16 November 2011, Intercontinental Hotel, Nairobi, Kenya. 
This natural drift towards negotiating tariff concessions is reinforced by the absence of reliable trade data for non-goods areas. This implies that - until trade data in services and other non-goods areas are upgraded and updated at a global level - the degree to which the WTO achieves its fundamental goals such as creating markets and lowering trade barriers can only be measured at a global level in the areas of goods. Thus most of the landmark studies published in the wake of the Uruguay Round, estimating inter alia that the gains from the Round could measure over US $\$ 200$ billion per year, were restricted to the gains in tariff liberalization only. ${ }^{24}$

In the case of the ACP countries, the bias is even stronger, given the lack of reliable trade data for most ACP countries. Several ACP countries (ranging from Haiti to Guinea-Bissau and Nauru) do not collect trade statistics of any kind, apart from sector-specific surveys of individual exporters. Region-wide or ACP-wide impact assessments of goods liberalization scenarios generally rely on mirror data (i.e. measuring imports into country $\mathrm{X}$ via the exports of trading partners to country $\mathrm{X}$ ) to fill in gaps, which in several instances leads to large measurement errors due to an inability to distinguish re-exports from imports for domestic use. For areas outside of basic goods imports and exports, such as services, bilateral trade data for most ACP countries is non-existent. As a result, trade researchers or policymakers attempting to measure the impact of even the most wide-ranging RTA are forced to narrow their most defensible conclusions on tariff liberalization.

These factors have not only narrowed the view of WTO compatibility to a tariff exercise, but also instilled a "fear of the unknown" at the national level when considering the costs and benefits of a trade package that includes areas outside of traditional market access. In the words of one of the African EPA coordinators interviewed for this paper, the tariff bias in the EPA negotiations came about because

It's what we could grasp... [Tariffs were] the only thing that could be concretely measured. Both sides knew that other areas - like services - were just as, if not more, important to our development as ACP countries, but there was no way of actually putting a number on their size of their impact. They were still seen as sectors that we didn't fully understand.

\section{Seven Perverse Consequences}

What happens, then, when negotiators are forced to realize wide-ranging, noncommercial, innovative development RTA objectives through the narrow, traditional, goods-based channel of WTO compatibility? This section argues that seven perverse consequences resulted from the fundamental trade-and-

\footnotetext{
${ }^{24}$ See a summary analysis in Will Martin and L. Alan Winters, "The Uruguay Round: Widening and Deepening the World Trading System", Directions in Development, World Bank, Washington, October 1995.
} 
development versus WTO-compatibility mismatch, each of which contributed to the current unsatisfactory EPA status quo.

\section{ACP Fragmentation}

The first consequence was the fragmentation of the ACP regional groupings. As noted earlier, the EPA negotiating configurations were based on geographical, political and historical affiliations; the overlap with common commercial concerns was in most cases minimal (i.e. apart from a handful of commodity exports). The collective undertaking assumed implicitly that all ACP countries within each grouping had either an equal interest in signing an EPA, or at least enough interest to craft a common WTO-compatible package.

When WTO considerations however narrowed the political energy of the negotiations towards achieving SAT in tariff liberalization, the dynamic of the negotiations shifted towards the sub-set of countries either (a) whose commodity exports into Europe benefited from preferential margins, and thus stood to lose the most from the lapsing of the Cotonou trade regime or (b) whose government revenues relied less heavily on border charges, and thus were less concerned with trade-related revenue losses.

As a result, in the case of the Pacific, only Fiji and Papua New Guinea signed a goodsonly interim agreement to protect their sugar and fish exports respectively. In Africa, a handful of countries signed interim EPAs to protect export interests such as cocoa. ${ }^{25}$ The irony of the remaining efforts to craft fully regional agreements in the Pacific and various African regions is that they are proceeding without the political pressure of precisely those key exporters to the EU that have already "locked in" their preferences via interim agreements. Thus the current negotiating configurations, in effect, are comprised of precisely those ACP constituencies who do not face any threat from the lapsing of preferential regimes. ${ }^{26}$

In the CARIFORUM context, a case can be made that the fragmentation did not occur due to the English-speaking CARICOM region's relatively deeper integration vis-àvis its African and Pacific partners, including a long-standing Common External Tariff and a history of active participation in trade issues both as individual states and as a Caribbean collective. This however ignores that even in the CARIFORUM case, there was a strong incentive solely on the goods side to be made for signing an

25 SADC: an interim EPA has been concluded with Botswana, Lesotho, Namibia, Swaziland and Mozambique in 2007. ESA: An interim EPA has been agreed with six ESA states: Comoros, Madagascar, Mauritius, Seychelles, Zambia and Zimbabwe. EAC: In 2007, the EAC countries (Kenya, Uganda, Tanzania, Burundi, Rwanda) initialled an interim EPA. ECOWAS: interim EPAs were signed with Ivory Coast (Côte d'Ivoire) and initialled with Ghana. Central Africa: Only Cameroon has signed an interim EPA.

${ }^{26}$ Conversely, the absence of key goods exporting sectors may actually benefit the EPA process by focusing the negotiations on newer areas of trade. 
agreement at the level of individual states. Unlike the other ACP regions, most Caribbean countries had at least one major goods export sector that would have been impacted by the imposition of GSP duties; exports from the region stood to face nearly US $\$ 300$ million in additional annual duties into the EU had the EPA not been signed. 27

Ironically, the concern that the EPA process would fragment the ACP was expressed early on by ACP advocates, and the decision to negotiate as seven separate regions, rather than a united ACP front, was highly controversial. ${ }^{28}$ However the actual EPA experience suggests that even if the 79 ACP States had negotiated as a single group, the focus on tariff liberalization - as the negotiating clock ticked down to the $1^{\text {st }}$ January 2008 - would have arguably still led to the division of the all-ACP grouping at the country level between those states with goods export interests to protect in Europe, and those without.

\section{SAT Shopping}

The second perverse consequence of the EPA's focus on achieving SAT in goods was a strong incentive for ACP concessions to be made on the basis of "SAT shopping". This term implies efforts to statistically comply with a given level of liberalization one assumed to be within the acceptable bounds of WTO Members' tolerance with respect to Article XXIV:8 - rather than a carefully considered balance of offensive and defensive interests.

For the EPA negotiations, many ACP countries' initial offers were crafted to reflect each country's policy goals, including revenue protection, domestic employment, food security and rural development. Many of these initial offers however often fell far short of complying with standard understandings of the SAT threshold, with the problem compounded significantly in those regions that strived from the outset to present a common exclusions list, i.e. where one country's exclusion applied to the EU imports of all members of the same regional grouping.

The initial offers thus required significant adjustment (particularly from the exclusions basket into the various phasing baskets). The "SAT shopping" came in the degree to which subsequent concessions (especially which products to remove from exclusions) were influenced not by the same policy choices that informed the initial offer (revenue, production etc), but by purely numerical considerations - that is, what level of imports were recorded against individual items. The linking of WTO

27 See "The Potential Impact of Losing Cotonou Preferences: A Preliminary Analysis for the Caribbean", Sacha Silva, report prepared for the Caribbean Regional Negotiating Machinery, Barbados, 2007.

For CARIFORUM, the key exports included sugar, bananas, alumina, rice, textiles, methanol, rum, crustaceans and fruit juices.

${ }^{28}$ Lorenz (2012). 
compatibility with the achievement of a single percentage value thus provided a strong incentive for ACP countries to both:

- Focus excessively on those items with large recorded import levels - or conversely, ignoring those products with low levels of imports - at the detriment of achieving consistent treatment across similar groups of products; and

- Choose data sources (e.g. mirror or national data) or base periods (i.e. depending on fluctuations in import levels) to minimize the actual liberalization required, rather than focus on developmental (including actual economic and trade) considerations.

In the case of the ACP, this "SAT shopping" is especially problematic given its basis on national trade data that is often an unreliable proxy for actual trade flows. ACP trade data, particularly in the smallest and poorest economies, are subject to inter alia misclassification of country of origin, the inclusion of re-exports, the exclusion of informal trade (a particular problem in African ACP countries), and lengthy delays in verification and consolidation of data from multiple entry ports. In certain SVEs and LDCs where trade flows with minor partners are weak or intermittently tied to large projects or procurements (as was the case with many ACP countries in the EPA), minor changes in the base period, or even a simple error in the Customs or Statistics Departments could easily lead to a dramatic shift in the calculation of SAT thresholds. ${ }^{29}$ In essence, critical decisions over market access concessions rested on the abilities of only two government departments to accurately record and verify trade flows, and on the capacity of national and regional negotiators to handle complex data files and spreadsheets.

The use of mirror data does little to rectify the problem: in early evaluations of the CARIFORUM-EU trade flows, little congruence was found between ACP national trade data and EU mirror data, with large differences in CIF and FOB ${ }^{30}$ values that could potentially substantially alter the overall calculation to achieve compliance with the SAT requirement. ${ }^{31}$ For example, a significant percentage of trade flows between the EU and CARICOM, based on EU data, was found to be in trade in vessels and sailboats of chapter 89 - virtually none of which were found in the CARICOM national data. Thus using EU mirror data, the achievement of the SAT requirement (and thus WTO compatibility of the entire EPA) could have been significantly assisted by liberalizing trade that, according to CARICOM's own understanding, did not even exist.

\footnotetext{
29 WTIA (2010).

${ }^{30}$ Cost, Insurance and Freight versus Free on Board.

${ }^{31}$ CARIFORUM national data was used in the final calculation/notification, apart from Haiti where EU mirror data was used.
} 
The "SAT shopping" incentive is also problematic in the case of future FTAs. While the irrationality of concessions on purely statistical grounds may cause minimal revenue or production impacts due to low levels of imports from the EU, future FTA partners - with much larger imports and thus where trade threats are more pronounced - are likely to demand the same line-by-line treatment from ACP countries. $^{32}$

\section{The "Right" Threshold}

The third perverse outcome of the EPA's tariff bias is that significant time and resources (both financial and human) were spent in debates over the "right" SAT level that failed to produce a mutually satisfactory or legally defensible outcome. Towards the end of the 2008 negotiating deadline, the EU was successful in arguing that ACP countries should liberalize $80 \%$ of their imports from the EU within a 15 year period - based on a total EU-ACP liberalization threshold of $90 \%$ when combined with the EU's offer of duty-free, quota-free treatment (i.e., 100\%) - with a maximum phasing period of 25 years. The $80 \%$ interpretation (like other percentages mooted in the WTO negotiations on RTAs) however does not have a strong legal basis within the GATT, and neither the means of measuring SAT nor its percentage threshold are a settled matter of law at the WTO. ${ }^{33}$ Article XXIV does not provide any guidance with respect to calculating coverage requirement, including the degree to which SAT can be achieved through asymmetric liberalization.

Thus the $80 \%$ EU proposal reflected a measure of political risk management rather than an actual legal interpretation. The question remains however as to whether those ACP countries that signed EPAs at the $80 \%$ threshold conceded too much or too little in the name of WTO compatibility - a question that may become more acute if the other ACP countries are able to secure better terms from the EU without a subsequent challenge from the WTO membership.

The 80\%-by-value threshold used by the EPA partners is also unsatisfactory given that other possible measurements to achieve the SAT requirement could have provided significantly more protection for some ACP countries. A liberalization threshold based on percentage of tariff lines, for example, does not rely on ambiguous definitions, nor does it dependent on the choice of base periods or data sources, given that the overall number of lines in any given national tariff is unlikely to change significantly over time, even with periodic revisions to the Harmonized System. It is easier to handle for ACP negotiators and easier for other parties to evaluate the level of liberalization in the agreement. Moreover, the concentration of North-South trade (especially for small economies) implies that large shares of

\footnotetext{
32 The use of the same "SAT shopping" approach in future RTA negotiations could cause even further problems if such a negotiation is conducted with a so-called "major trading economy" as defined under the EPA's MFN Clause, and thus where commitments would then apply to EU imports.

33 WTO (2002).
} 
revenue can be protected in a small share of tariff lines, even with a high liberalization threshold. Using the share-of-import-value approach currently favoured by the EU, however, results in significantly higher revenue losses, since there is a direct link between import values and border revenues.

The discussion is further confused by the consideration of under what circumstances ACP countries' liberalization should be considered collectively, or as individual countries. For example, in the Pacific region Fiji and Papua New Guinea have already signed goods-only EPAs. How then should liberalization by other Pacific Island countries be considered, in the event that they are able to conclude EPAs? Should Nauru and the Cook Islands individually be held to the same $80 \%$ standard as Fiji and Papua New Guinea, simply because they concluded at a different time, or will their contribution be considered as part of a regional Pacific-wide effort? ${ }^{34}$ In the case in the CARIFORUM, the collective approach to measuring SAT meant that small developing economies such as the members of the Organization of Eastern Caribbean States (OECS) were able to liberalize much less than the larger Caribbean economies such as the Dominican Republic, Trinidad and Tobago, Jamaica and Barbados - as well as, oddly, Haiti, the only LDC. In the Pacific and African cases however negotiators in individual countries are preparing individual national offers that meet the $80 \%$ threshold, even in the case of some LDCs. The lack of clarity has also led to conflicts between larger and smaller ACP countries about the possibility of the latter "free-riding" on the liberalization of the former.

\section{A Race to the Bottom}

The fourth consequence of the EPA's goods focus was a slow and expensive "race to the bottom" with respect to the crafting of goods offers. As noted in Section II, SVE and LDC ACP countries expected little additional export benefit on the tariff side from the EPA, given the gradual erosion of preferential margins on traditional commodities from inter alia bilateral agreements with non-ACP partners and changes in the EU's internal market arrangements. Thus the benefit of securing duty-free, quota-free access was often "emotionally" lost at the outset and/or seen by ACP stakeholders at best as a medium-term benefit. Without an offsetting benefit on the goods export side to sell politically at home, the crafting of EPA goods offers thus became a purely defensive exercise where ACP countries have an incentive to create offers purely to minimize any revenue or production impacts: removing tariffs only on items that attract low rates, or where little recorded trade exists. The ACP offers thus in most cases avoid any significant market opening, thus foregoing any real benefits in terms of market access (for the EU) or stronger domestic competition or lower consumer prices (for the ACP).

\footnotetext{
34 The latter option would allow significantly lower liberalization by the rest of the Pacific ACP countries, given that two-thirds of tariff lines in the Papua New Guinea national tariff are already zero-rated on an MFN basis.
} 
The $80 \%$ SAT threshold however still needed to be satisfied, and in a context where revenue losses and debt sustainability are constant concerns within the ACP (particularly following the 2008-9 financial crisis), the process of creating an "acceptable" goods offer was reduced to lengthy, resource-consuming and politically painful process of internal negotiation. In the CARIFORUM case for example, ten out of fifteen negotiating rounds passed before an offer was tabled. Despite the ten-year period since the launch of the EPA, West Africa only tabled its market access offer in 2010; as of writing (2012) the COMESA, Central African, West African, and the Pacific Islands have yet to agree on common regional positions. ${ }^{35}$

While the financial cost of the negotiations was often underwritten by the EU and other donors, the opportunity cost from the diversion of scarce human resources was borne disproportionately by the ACP, whose often under-paid and underresourced officials within Trade and other key Ministries have been burdened by EPA-related work since at least 2004, in a context where trade negotiations are only one part of many officials' portfolios. While there have been undoubted capacitybuilding benefits from the EPA process for ACP officials - particularly as their countries face new North-South negotiations with partners eager to maintain parity with the Europeans - the question could be easily asked whether those training benefits could be have been secured in a more cost- and time-effective way.

\section{Unbalanced Commitments}

The fifth outcome was a clear imbalance in the ambition of ACP commitments - that is, between ambitious goods offers (driven by the need to satisfy Article XXIV) and relatively unambitious offers in non-goods areas (in the absence of a similarly stringent Article XXIV-type discipline). Using the CARIFORUM case as an example, the final tariff liberalization schedule (using the original 2002-2004 base period) will yield nearly US $\$ 150$ million in annual theoretical revenue losses once all tariff reduction commitments have been effected over the 25-year implementation period. ${ }^{36}$ While this estimated loss is a relatively small $(6 \%)$ share of the nearly US $\$ 2.5$ billion in CARIFORUM imports from the EU over the same base period, they are arguably significant and ambitious given the EU's status as a relatively minor trading partner for most of the Caribbean (apart from Suriname), and given the severe fiscal challenges facing nearly all CARIFORUM countries. Particularly in a "SAT shopping" context, this level of ambition reflected in the final goods schedules was largely due to the need to achieve compliance with Article XXIV, rather than

\footnotetext{
${ }^{35}$ European Parliament (2012).

36 Estimates based on own calculations (Silva) and do not include the losses from either the implementation of the regional preference or MFN clauses. Nearly one-third of these estimated losses are borne by the Dominican Republic, due to its significantly lower number of exclusions vis-à-vis the CARICOM Member States. This estimate is based on the arguably questionable assumptions that (a) trade flows will remain static over the 25-year period and (b) that theoretical revenue estimates are an accurate proxy for actual revenue collections.
} 
goods liberalization and market opening being the centrepiece of ACP countries' negotiating strategies.

In comparison, the CARIFORUM services schedules - while representing a large increasing in sectoral coverage vis-à-vis existing WTO commitments - are largely in sectors of low commercial value. The trade facilitation commitments by CARIFORUM rely heavily on exhortatory and/or best endeavour language, despite the potential for trade facilitation reforms to reduce business costs and increase market access. In the other EPA regions (Africa and the Pacific), the interim EPA texts focused exclusively or primarily on goods, although negotiations in other areas are ongoing. ${ }^{37}$ Once again, while the $\mathrm{EU}$ and regional negotiators and some domestic stakeholders pressed for a more ambitious approach in these non-goods areas, in a political environment marred by a single-minded focus on a narrow understanding of Article XXIV and its SAT requirement the absence of a threat of legal challenge from the WTO for those other issues implied a perspective that such liberalization was not "required" by the ACP, and thus ended up being largely (or entirely) absent from the final EPA package.

\section{Pressure on LDCs and Unilateral Reformers}

The sixth perverse outcome of the EPA's goods bias was its unbalanced pressure for liberalization commitments by LDCs ${ }^{38}$ and those ACP countries that had already undertaken significant unilateral tariff reductions prior to the EPA.

In the case of the LDCs, these countries are already provided duty-free entry into the EU market through the Everything But Arms (EBA) initiative, and are exempt from tariff reduction commitments under the Doha draft texts. The EPAs however placed some LDCs in the position of having to choose between either maintaining this nonreciprocal acquis - thus shifting the burden of liberalization onto their regional neighbours, and creating intra-regional tensions and accusations of free-riding - or relinquishing their benefits as LDCs in order to contribute to the regional liberalization effort. In Africa for example, several LDCs (i.e. Lesotho, Mozambique, Comoros, Madagascar, Zambia, and all of the EAC Members minus Kenya) eventually signed up to an EPA, as did Haiti in the Caribbean; several Pacific Island LDCs are also in the process of preparing and submitting offers that involve tariff reduction.

In the case of some LDCs, their large population - in Haiti's case, larger than the rest of its regional neighbours combined, and in Papua New Guinea, twice as large - their low level of industrial development, and often low applied rates (given that many

37 European Parliament (2012). The Fiji and PNG interim agreements also include safeguard provisions, provisions on technical barriers to trade, rules of origin, SPS measures and customs and trade facilitation.

${ }^{38}$ All references to LDCs in this paper are to those designated as such by the United Nations, in order to distinguish them from the specific ACP regional LDC designations (i.e. within CARICOM and the Pacific Islands Forum). 
LDCs have undergone structural adjustment programs in the past) result in higher levels of imports relative to their more industrially-developed regional neighbours. For precisely this reason, their contribution or non-contribution to the liberalization effort can either decisively tip the region over the SAT threshold, or require other States - many of which face the same fiscal and economic problems - to increase their contribution. In Haiti's case for example, its level of liberalization ${ }^{39}$ was higher both in percentage and in volume terms than most of its CARIFORUM counterparts that are not UN-designated LDCs. ${ }^{40}$

For similar reasons, ACP countries that had already undertaken unilateral tariff reforms prior to the launch of the EPA - such as Jamaica, the Dominican Republic, Haiti and Papua New Guinea - faced particularly strong pressure to make tariff concessions. As with the LDCs, lower tariffs and in some cases higher populations attracted higher import levels than their more protectionist neighbours. This implied that the tariff-SAT focus created a perverse system that essentially rewarded the more protectionist countries where high/prohibitive tariffs had impeded imports (i.e. since their contribution to achieving SAT would be minimal), and placed more pressure on the low-tariff/high-import reformers to carry the regional liberalization effort over the required SAT threshold.

\section{Why Implement and Why Engage?}

Finally, the EPA's focus on tariff reduction has led to a reluctance within the ACP to both implement existing commitments, and engage in future RTA negotiations, even where recognizable benefits could accrue.

In trade negotiations, concessions by an individual party are normally the result of pressures by exporters abroad and importers at home seeking to gain commercial advantage; a similar logic creates pressures on governments to implement RTA commitments once the negotiations conclude. In a scenario of "SAT shopping" however where concessions are based on numbers and arbitrary choices over time periods and data sources, where is the constituency with a commercial incentive to push for implementation? How can governments be encouraged to implement concessions that are viewed as arbitrary impositions, viewed solely through the lens of their negative impacts on revenue and production, and where the only incentive to implement is the threat of legal action for a violation of commitments under the agreement? Thus rather than the original vision of a stepping-stone towards trade integration and development, the implementation of EPA commitments becomes an initiative largely promoted and supported by the same developed-country negotiating partner - now switching from their role as trade negotiating partner to

\footnotetext{
${ }^{39}$ As measured by the size, in US\$ import values, of the immediate zero-binding and various phased reduction baskets.

${ }^{40}$ Based on own calculations (Silva) using national and mirror trade data.
} 
their role as donor - and another item in the increasingly full inbox of ACP trade officials. ${ }^{41}$

The focus of WTO compatibility debates on tariff reductions also impacted and impacts the willingness of developing countries to engage in future RTA negotiations. In the case of the Pacific Islands for example a number of negotiators have privately stated that they recognize the potential benefits of a trade and development agreement with Australia and New Zealand (under the PACER Plus umbrella), particularly in areas such as investment and labour mobility. Yet the EPA experience, particularly the focus on Article XXIV and the potential tariff losses given that Australia and New Zealand are major trading partners of the Pacific ACP countries - has led to a noticeable lack of political will among the Pacific ACP to actively engage in the PACER Plus process. Similarly, the rationale for countries such as Nigeria not to conclude an EPA with the EC is directly linked to the issue of tariff liberalization thresholds, despite the open acknowledgement by some African Ministers that their Member States could potentially benefit from other areas of the EPA. ${ }^{42}$

\section{Re-Thinking Reciprocity}

Despite the push within the WTO to clarify existing disciplines on RTAs, there has been resistance from some WTO Members who prefer the ambiguity of the current framework and would have little incentive to undermine their options in this area by streamlining the various obligations embedded in GATT. ${ }^{43}$ This group no doubt includes some developing countries, fearing that mutually agreed thresholds could lead to excessive scrutiny of RTAs to which they are (or may become) signatories. ${ }^{44}$ The EPA experience however suggests that the narrow and quantitative interpretations of what is perceived as a WTO compatible threshold can easily lead to the singular focus on a subset of considerations, to the detriment of the other goals embedded in the RTA, and indeed in the WTO itself.

More importantly, the EPA experience suggests that the primary focus of proposals tabled within the initial debate on S\&D flexibilities within RTA disciplines - that is,

\footnotetext{
${ }^{41}$ See "EU EPAs Not a Priority", DevSur, September 3, 2012, available online at www.devsur.com; "Implementing the Economic Partnership Agreement: Challenges and Bottlenecks in the CARIFORUM Region", European Centre for Development Policy Management, Maastricht,

42 See "Africans Fear 'Ruin' in Europe Trade Talks", Africa Renewal Vol 21 \#2, United Nations Department of Public Information, New York, July 2007. For an example in the Nigerian context, see Nwoke (2008), "Nigeria and the Challenge of the EPA", Trade Negotiating Insights (Volume 7, Number 9), International Centre for Trade and Sustainable Development, Geneva, November 2008; available online at http://ictsd.org/i/news/tni/32924.

43 Mavroidis (2005).

${ }^{44}$ Hence the number of WTO Members who, in their RTA proposals summarized in Table 1, emphasized that new rules should only apply to new RTAs.
} 
re-examining and/or expanding existing provisions under Article XXIV, by inter alia looking for lower thresholds, or longer transition periods - would not achieve the pro-development outcome sought under the new RTA archetype, given that the perspective remains fundamentally flawed. A continued focus on goods and tariff reduction could still split developing-country alliances and regional integration projects by manufacturing export profiles; liberalization concessions based on "SAT shopping" around a $40 \%$ threshold would likely make as little economic sense as concessions using a 90\% threshold based on the same approach; and trade negotiating partners would still have an incentive to ignore trade liberalization on other areas of the value chain. These ignored areas are precisely those increasingly recognized as the future not only of the trade and development nexus but more broadly of international trade as such, now increasingly and rightly understood as an integrated challenge of building and connecting comprehensive value chains which depends on a great range of factors, with the regulation and taxation of goods crossing borders being just one of them.

WTO Reform: A Wider, Value-Chain Approach to Measuring SAT

One key element of avoiding a reflexive tariff focus, particularly in trade and development RTAs, is to fix the incentive signals that the multilateral system sends to RTA negotiating parties.

This "fix" requires a much more ambitious overhaul, or re-interpretation, of RTA disciplines than those originally proposed in the first post-Doha debates. The EPA experience suggests that the original S\&D proposals for RTAs contained a similar flaw: they focused on the existing WTO provisions on RTAs as traditionally understood, rather than imagining that the system could and should be re-assessed and thus widened or fundamentally altered. Yet the perverse outcomes identified in the EPA context imply that simply tinkering around the edges of Article XXIV - i.e. establishing a lower SAT level, or allowing for exceptionally long transition periods - would still result in negotiations being overly focused on goods, and still create all of the negative unintended consequences (SAT shopping, fragmentation, pressure on LDCs, etc) identified earlier. If the original vision of the EPA was the correct one - i.e. that a truly $21^{\text {st }}$ century trade and development agreement needs to look beyond traditional areas of market access, and bring SVEs and LDCs into a wider WTO agenda, while remaining within its legal disciplines - then the idea of "WTO compatibility" must expand to accommodate this vision. In short, if the legal incentives emanating from the traditional WTO system (as previously understood) send the wrong signals to RTA partners, then the signals should change.

The reform needed implies a fundamental re-thinking of reciprocity, particularly for (but crucially not limited to) North-South trade and development RTAs. The reform should ideally take the form of a mechanism that allows countries to balance their concessions between different areas of the negotiations. As noted in several parts of this paper, the perverse EPA outcomes largely stemmed from the fact that history 
and the existence of only a single stringent legal obligation (e.g. Article XXIV GATT) in the WTO system created, in the EPA context, an undue focus on one single area of the negotiations - one not considered as a primary source of systemic trade and development benefits.

The ideal understanding of RTA disciplines would essentially redefine SAT to consider commitments in all areas of the negotiations - whether in services, TBT, trade facilitation or Aid-for-Trade - as long as they contribute to the WTO's objectives, which extend far beyond simple GATT-style market access. Thus rather than automatically focusing from the outset on goods liberalization, RTA partners would have not only a practical commercial but WTO legal incentive to look at other areas of the negotiations, particularly those elements in the value chain that actually create trade and generate development.

In practice, this would mean that in a North-South negotiating setting, a developing country could choose to achieve less-than-SAT levels of tariff liberalization particularly when such commitments would not be a primary source of traderelated development benefits - and opt instead to make balancing concessions in another area of the negotiations, one where both parties agree that the objectives of the agreement would be more tangible achieved.

The approach is not without precedent in the WTO. Australia, in its submission to the 1999 Ministerial Conference in Seattle, called on Members to "decide whether the various WTO rules on RTAs should be integrated into a single framework, including whether 'substantially all the trade' (Article XXIV) should be measured in terms of goods and services together" (emphasis added). ${ }^{45}$ The approach is also found in Article V:2 GATS, which states that in the evaluation of whether an RTA liberalizes "substantially all discrimination", consideration may be given to the relationship of the RTA to "a wider process of economic integration or trade liberalization". 46

A tangible reason for, and practical application of this approach is shown in Figure 1 below, which shows the contribution of different costs of production - from retail, to feed production, processing and distribution- to the final consumer price for poultry meat in Barbados. Given the actual distribution of costs, a truly trade and development approach - i.e. one concerned with lowering the cost of poultry for Barbadian consumers and/or increasing the competitiveness of poultry exports from Barbados - would likely not primarily encourage Barbados to reduce its (very high) tariffs on poultry. Instead, a WTO discipline focused on maximising overall

${ }^{45}$ See "Proposal on Regional Trade Agreements: Communication from Australia", WT/GC/W/183, 19 May 1999, World Trade Organization, Switzerland.

46 Following Cottier and Molinuevo (2008), the term "wider process of economic integration" is understood to refer to liberalization in trade in goods per Article XXIV. There is however no a priori reason why "economic integration" could not extend to other areas of negotiation such as trade facilitation or Aid-for-Trade, or why the approach must be limited to tariff reduction only. 
trade (and development) benefits should provide Barbados with the ability alternatively or cumulatively, in a tailored balance, to maintain (some of) its tariffs on poultry, but balance this lack of tariff reduction with commitments in retail and distribution services (41\% of the consumer price), and/or use Aid-for-Trade funds to improve regional feed sourcing (36\%), and/or commit to improving SPS standards in farming and hatcheries $(20 \%)$.

Figure 1: Contribution to Costs in Barbados Poultry Industry

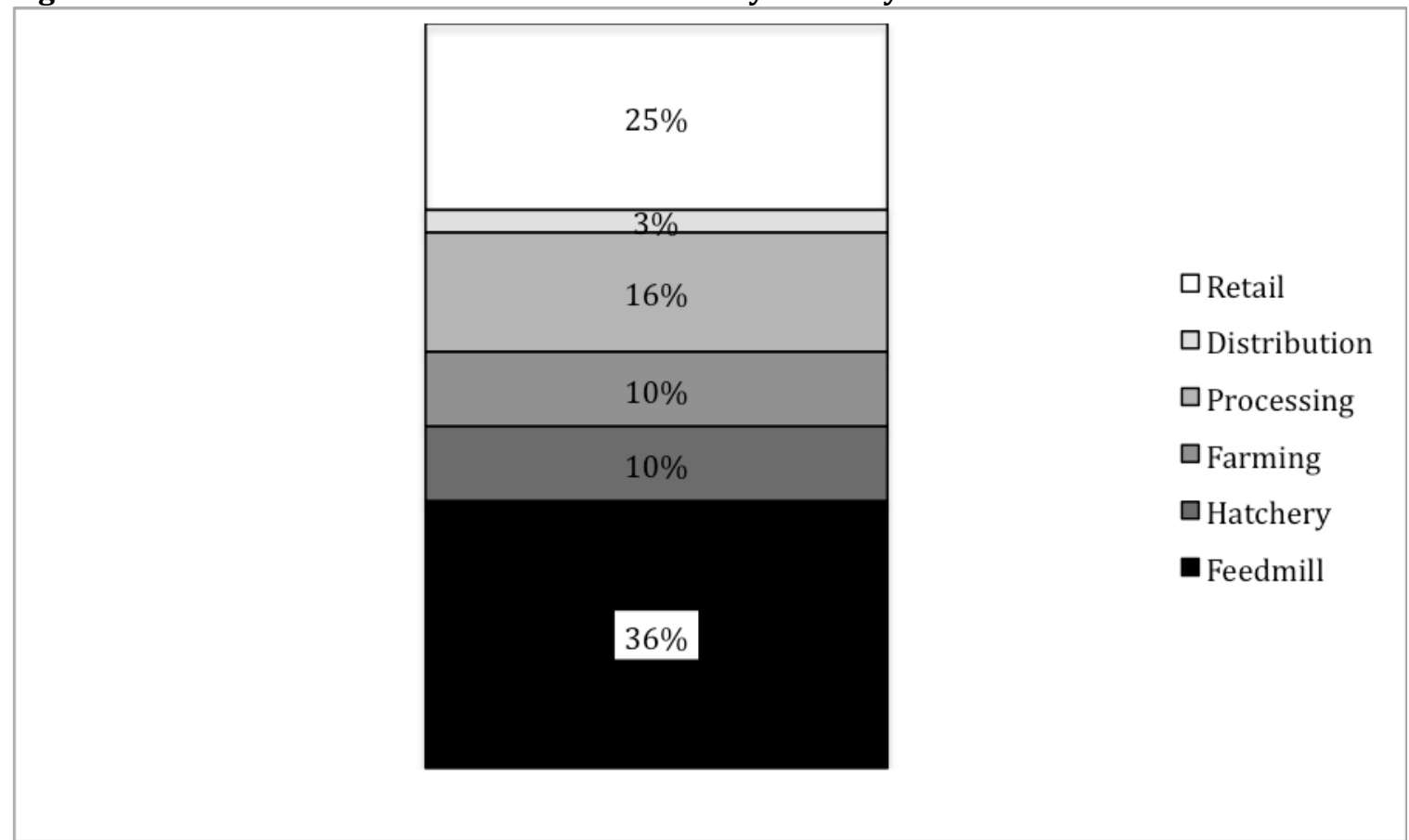

Source: Robert Best, "CARICOM Poultry Industry: Changing Competitive Environment \& Evolving Response", Presentation at 'Strengthening Agricultural Trade Strategies: Towards a Caribbean Agenda', 6 - 8 November 2008, Belize City, Belize.

The inclusion of something as non-classical as an Aid-for-Trade commitment in an assessment of trade liberalization may appear surprising at first. Consider however the building of a new road system in the banana-producing regions in Cameroon, or the rebuilding of the main sea-port in Haiti. If Aid-for-Trade commitments for these initiatives result in increases in trade levels for these two countries and their trading partners, there is little reason why their contribution should be downgraded vis-à-vis tariff reductions in the overall assessment of WTO compatibility. A similar logic applies to Aid-for-Trade funds being used to implement a complete overhaul of Customs procedures, which in practice may result in much more systemic and deeper trade benefits that simple tariff reduction.

This approach is, in fact, not revolutionary. Rather, it reflects the very rationale for the movement of the GATT to the WTO - i.e. the realization that trade involves much more than just tariff reductions - as well as recent thinking on " $21^{\text {st }}$ Century Regionalism": RTA objectives that are qualitatively different to that of previous 
decades, looking beyond the traditional exchange of market access. ${ }^{47}$ The new view of regionalism sees:

\begin{abstract}
an intertwining of: 1) trade in goods, 2) international investment in production facilities, training, technology and long-term business relationships, and 3) the use of infrastructure services to coordinate the dispersed production, especially services such as telecoms, internet, express parcel delivery, air cargo, trade-related finance, customs clearance services, etc. This could be called the trade-investment-services nexus.... Bringing high-quality, competitively-priced goods to customers in a timely manner requires international coordination of production facilities via the continuous two-way flow of goods, people, ideas and investments. ${ }^{48}$
\end{abstract}

As manufacturing has expanded into new products and new markets, WTO Members are increasingly seeing their economic future tied to global value chains; being part of the increasingly complex value-added linkages of primary, intermediate and finished goods is now considered the sina qua non of economic development, particularly in emerging and developing countries. These value chains are, as Baldwin points out, expanding far beyond traditional market access and tariffs in particular, and impacting the work of the WTO (e.g. through its "Made in the World" initiative) ${ }^{49}$. For Baldwin, the key RTA outcomes from a trade perspective are behind-the-border and regulatory measures, not the Vinerian tariff commitments that underpinned traditional WTO disciplines. The WTO's World Trade Report has even identified four "core" disciplines in deep RTAs that go beyond WTO agreements: competition policy (covered by $47 \%$ of all agreements in the WTO database), movement of capital (39\%), intellectual property rights not in the TRIPs Agreement (37\%), and investment not covered by GATT 1994 (31\%).50 This new reality of regionalism however is largely sidelined by the narrow focus on the traditional Article XXIV GATT framework - more easily measurable/tangible tariff reductions to achieve WTO compatibility.

The point of this suggestion, fundamentally, is thus not to depart from the economic and systemic rationale for tolerating RTAs; to the contrary, it means following and implementing that very same logic in today's world economy and today's WTO system, respecting the original thinking behind Article XXIV precisely by avoiding an anachronistically narrowed focus on goods only because the genesis of the WTO system of agreements has left us, somewhat by accident, with RTA disciplines in goods only, crafted at a time when the system only dealt with goods. This suggestion is firmly rooted in the WTO system as it stands today, even more so in WTO negotiations and discourse as they have evolved over the past decade, and - perhaps most importantly - in the nature of trade in the $21^{\text {st }}$ century as a complex network of cross-border, often regional or global value chains ("trade in tasks").

\footnotetext{
${ }^{47}$ Baldwin (2011).

${ }^{48}$ Baldwin (2011).

${ }^{49}$ See the MIWI website at http://www.wto.org/english/res_e/statis_e/miwi_e/miwi_e.htm

50 WTO (2012).
} 
It is worth noting the obvious in this context: The WTO system is one that integrates the multiple aspects of what trade means today, rather than an agglomeration of more or less parallel (but unconnected) systems of rules for goods, services, IPRs and other matters. This is reflected not only in the "single undertaking" approach practiced in trade rounds, such as the DDA, but also in the practical legal operation of the system, for example in the context of retaliatory measures under the Dispute Settlement Understanding which foresees the possibility of cross-retaliation across sectors and agreements. If such cross-retaliation is considered an appropriate measure to balance out violations of one agreement with the withdrawal of benefits under other agreements, it would appear to be only logical to apply the same logic in the context of disciplining RTAs.

\section{WTO disciplines on regional trade agreements}

In this section we argue that the traditional understanding of Article XXIV is based on an economic misconception that does not achieve its objective of permitting the benefits of regional trade agreements for the parties and for global welfare, while still, as far as possible, protecting third parties from the discriminatory effects of these agreements. Moreover, we propose that the WTO rules are currently missing a trick: focused as they are on harm to third countries, they give no credit where credit is due, namely, for the multilateral benefits of regional integration.

\section{Article XXIV as a Protection for Third Countries}

Article XXIV is designed to balance competing interests. It seeks to permit some forms of discriminatory liberalisation between regional trade agreement partners while at the same time ensuring that third parties are not thereby harmed. ${ }^{51}$ One way that they are harmed is obvious, and just as obviously prohibited. Article XXIV:5 states that the formation of a regional trade agreement should not be the occasion for raising trade barriers to trade with third parties. But the more complicated question concerns the implicit effects of discrimination against third countries.

In the 1940s, when Article XXIV:8 was drafted, it was widely assumed that partial free trade agreements (often then called 'preferential' trade agreements) were more discriminatory than full free trade agreements, and should therefore be discouraged. This thinking is exemplified in this often-quoted statement by US State Department official Clair Wilcox:

A customs union creates a wider trading area, removes obstacles to competition, makes possible a more economic allocation of resources and thus operates to increase production and raise planes of living. A preferential system, on the other hand, retains internal barriers, obstructs economy in production, and restrains the growth of income

\footnotetext{
${ }^{51}$ Formally speaking, Article XXIV GATT is an exception to other WTO rules, most notably the mostfavoured-nation obligation in Article I:1 GATT.
} 
and demand. It is set for the purpose of conferring a privilege on producers within the system and imposing a handicap on external competitors. A customs union is conducive to the expansion of trade on a basis of multilateralism and non-discrimination; a preferential system is not. ${ }^{52}$

It was soon realised that this distinction between full and partial trade agreements makes little economic sense. In 1963 Kenneth Dam scathingly called this paragraph a "non-argument", typical of the "confusion of thought" towards preferential trade agreements at the time. ${ }^{53}$ Nonetheless, this is the basis of the "substantially all the trade" requirement in Article XXIV:8. In summary, "true" free trade agreements could be permitted, but "partial" free trade agreements not, on the basis that they were somehow more discriminatory.

Indeed, from an economic perspective, the timing of Article XXIV:8 was unfortunate. Only a few years after its adoption, Jacob Viner published The Customs Union Issue, ${ }^{54}$ which for the first time theorized the basic merits and demerits of regional trade agreements. For Viner, a regional trade agreement should be permitted when its trade creating effects (displacement of domestic products by member products) outweighs its trade diverting effect (displacement of non-member products by member products). This test has been refined over the years, but still remains broadly valid. The problem, as James Mathis explains, ${ }^{55}$ is that that Article XXIV is not a good proxy for implementing this test.

The problem is on both sides of the equation. As far as trade creation is concerned, it cannot be assumed that eliminating trade barriers on a smaller range of goods is significantly more conducive to trade creation than reducing trade barriers on a larger range. As for trade diversion, it is obvious that the more sectors are liberalized in a free trade agreement, the more chance there is of trade diversion. ${ }^{56}$ But even this is complicated, because, as Lipsey pointed out after Viner, trade diversion is not always negative in welfare terms. Consumers may benefit from lower prices, a result of trade diversion, and in turn increase their consumption of (other) non-member goods. ${ }^{57}$ From an economic perspective, it is therefore generally agreed that Article XXIV:8 does not do what was intended: to provide a

\footnotetext{
52 Wilcox (1949), at 70-71.

${ }^{53}$ Dam described the first two sentences as 'a statement of the alleged differences between customs unions and preferential arrangements' the third as stating a purpose that could just as easily be attributed to customs unions, and the fourth as 'simply the author's conclusion.' Kenneth Dam (1963), at 633-4, n 47.

${ }^{54}$ While it was common at the time to use the term 'customs union', in fact Viner's analysis focused on free trade agreements: Bhagwati (2008), $17 \mathrm{n} 1$.

55 Mathis (2002), Ch 6.

56 This rather obvious point was theorised by Meade (1955). Theoretically it is possible to reduce zero diversion by reducing external trade barriers: Kemp and Wan (1976). But this is not required, not in practice done.

${ }^{57}$ Lipsey (1957).
} 
rule that allows trade agreements that are beneficial for world trade (and the parties to those agreements) at minimum cost to third parties.

There is a counterargument: that Article XXIV:8 never really had much to do with economics, and should not be tested in this way. There are two aspects to this argument. The first is that the requirement staves off the political pressure to negotiate agreements whose benefits lie in trade diversion rather than trade creation. This remains a powerful rationale for a strict requirement in principle, but also arguably bloodless in the sense that it presumes one economic effect (trade diversion) while ignoring another (trade creation) and, fundamentally, without looking at the details, which in economic policy makes little sense. The second aspect of this argument might once have had traction, but no longer. This is that the true purpose of the "substantially all the trade" test is to establish such a difficult hurdle for any negotiators that free trade agreements would be very rare, limited to those which are the most legitimate (in terms of resembling nation state internal markets) and the most difficult to establish. ${ }^{58}$ But this rationale has been overtaken by events. Hundreds of free trade agreements have been concluded in the last twenty years, each spurred by the need to recovering market access lost to another free trade agreement with a rival. ${ }^{59}$ This domino effect seems to be more powerful than the need to comply with Article XXIV:8.

In sum, the 'substantially all the trade' requirement in Article XXIV:8 has little current justification other than to operate as a general and imprecise constraint on negotiators minded to focus on less domestically harmful commitments. If this risk can be accounted for in some other way, the traditional rationale for Article XXIV:8 disappears. For the purposes of this paper, this means that Article XXIV:8 should not be treated as a talisman. It does not do what it was supposed to do.

But our argument goes beyond this. We propose reforming Article XXIV:8, as it is traditionally understood, by allowing it to do something that was arguably inherent in its very purpose, namely to encourage those aspects of free trade agreements which are of benefit to third countries, and to global welfare. Traditional thinking on free trade agreements has concentrated on external barriers to trade. But as Richard Baldwin has recently written, this is $20^{\text {th }}$ century thinking that no longer applies to what he terms ' $21^{\text {st }}$ century regionalism'.60 Baldwin identifies a number of areas where discrimination between trading partners is particularly difficult: in services regulation, for example (especially for large transnational firms that dominate global trade), or competition policy (given its basis on rules delimiting forbidden behaviours without regard to the nationality of the defendant or plaintiff), or technical barriers to trade, which admit little room for discriminating product by origin. ${ }^{61}$ In these areas, a legal framework that encourages deep commitments

\footnotetext{
${ }^{58}$ See Bhagwati (1993).

${ }^{59}$ Baldwin and Jaimovich (2010).

${ }^{60}$ Baldwin (2011).

${ }^{61}$ Baldwin (2011).
} 
creates "win-win" situation whereby development gains occur through systemic trade reforms in the developing-country partner, and trade gains occur as third countries benefit by a stronger RTA focus on non-discriminatory commitments.

Based on this, we suggest that a re-conceptualization of Article XXIV should take these multilateral benefits into account. This re-conceptualization could mean that RTA commitments with systemic benefit for third parties, or where discrimination between trading partners is difficult in practice (e.g. strengthening regulatory regimes in SPS or intellectual property, building more transparent and accountable trade defence mechanisms) could be given greater weight in the overall SAT assessment (or the standard which replaces it). Just as a wider value-chain approach would encourage RTA partners to look beyond tariffs and into the new/emerging areas of trade and development, a non-discrimination "bonus" would encourage the formation of RTAs that promote trade for all WTO Members, and potentially slow the cascade of retaliatory RTA formation.

The re-conceptualization would allow the WTO's RTA disciplines to avoid, or rather: reduce to its actual level of relevance, the traditional dichotomy between the interests of the RTA partners and the interests of excluded countries. By providing incentives to be ambitious in non-discriminatory areas, the disciplines can simultaneously serve the interests of negotiating parties, third countries and even overall global welfare.

\section{Legal Reassessment and Legal Reforms}

How can the above considerations be reflected in WTO RTA disciplines? The fundamental starting point of any discussion here must be the observation which has transpired throughout this paper: The classical reading of Article XXIV GATT, combined with the weak implementation of Article V GATS and the absence of any other RTA disciplines, has led to a perverse systemic outcome: Article XXIV de facto (and thereby de jure) operates as the system's main RTA discipline, but when interpreted only in its original GATT context leads to outcomes which are fundamentally at odds with its very rationale and purpose, namely to allow systemically "good" RTAs and prohibit systemically "bad" ones. Our proposal, therefore, can be fundamentally understood as one to resurrect the "real" Article $\mathrm{XXIV}$ as it was perhaps originally understood, but now logically encompassing more than just goods and tariffs, or at least as its rationale (and perhaps even its mechanics) should be understood in the context of the $21^{\text {st }}$ century's World Trading System.

\section{Re-Interpreting Article XXIV?}

If this understanding is sound in (economic and political) principle, as we suggest, the first legal point of call would be the question whether Article XXIV GATT 
(together with Article V GATS) could be interpreted to mean what it should mean. This may appear radical, but is perhaps less so than it seems.

In exchange for accepting Article XXIV's role of the WTO (not just the GATT) system's overall RTA discipline, which it has somewhat accidentally assumed for the reasons discussed above, the text, context and object and purpose of Article XXIV could be reassessed as now encompassing more than what it has so far been understood to cover. More specifically: The term "trade" in "substantially all the trade" could be re-assessed to encompass not only trade in goods but all traderelated aspects of the WTO system, present (services, TBT/SPS, etc.), emerging (trade facilitation, domestic regulation in services, Aid for Trade etc.) and future. While the text of Article XXIV:8(a)(i), addressing the case of customs unions, speaks of "substantially all the trade in products" and thus does not easily lend itself to such broadening, the text of subparagraph (b), addressing the case of FTAs, only speaks of "substantially all the trade." While it is clear that classical contextual interpretation would tend to view both together and in parallel, a broadened understanding of the relevant context of the provision (namely, the broader WTO context as a whole, into which Article XXIV has arguably migrated) could be read to include in "trade" more than just trade in goods, in the case of FTAs. ${ }^{62}$

This re-assessment would find powerful backing in the object and purpose of the provision, as reflected above. If the object and purpose of Article XXIV GATT (and Article V GATS) - and, more broadly, the treaty it is part of (not only GATT, but also the WTO Agreement with all its annexes) - is to accommodate those RTAs which are beneficial for the system and its Members, and prohibit those that are not, then the proposed re-interpretation of the provision serves this purpose obviously better than the traditional approach.

\section{Alternatively or Cumulatively: Possible Reform Approaches}

While individual WTO Members could make an attempt to simply advance (act on) the above interpretation in practice, we of course recognize that there may be political as well as systemic reasons for them not to take that route. These may include the unwillingness to put their fate into the hands of the Appellate Body whose critical eye would likely be prompted to examine the new interpretation sooner rather than later.

The alternative (or rather: cumulative) approach would be to seek to agree collectively on explicit reforms which reflect the above. This could be imagined in different forms.

62 The remaining narrower treatment in the context of customs unions would not be absurd; these unions are not only closer in principle but also already terminologically - "customs" - imply a goods focus. 


\section{Procedural Approach}

In proposing concrete legal reforms, there is a initial question whether, instead of a multilateral discipline, there could simply be multilateral control on an ad hoc basis, much as is the case with accession negotiations - in other words: a purely procedural requirement whereby Members can authorize RTAs if they so choose (possibly underpinned by general criteria articulating systemic interests, such as trade creation outweighing trade diversion). This would leave it to WTO Members to assess the merits of free trade agreements brought before them, and would encourage those proposing such agreements to include multilateral benefits in those agreements from which others could benefit as well. The apparent downside to this would be a lack of protection for those parties, which might find themselves arbitrarily blocked from forming new agreements. A lack of substantive discipline may also miss the opportunity to send a signal to RTA negotiators as to the types of agreements that are most likely to be of value to third countries.

On this basis, we would suggest that some degree of substantive discipline is valuable. However, it should be one that respects reality and does not (as is currently the case) replace it with a crude rule which may have originally been based on a mixture of crude economics and a desire to limit free trade agreements altogether.

\section{Formal Treaty Amendment}

Legally a substantial overhaul of the current RTA disciplines taking fully into account the holistic perspective as advocated here would be desirable and technically feasible, but possibly politically difficult as WTO Members currently find it very difficult to agree on any formal changes to the legal system they established in 1995.

\section{Declaration}

However, it appears legally possible to implement important aspects of our proposal with minimal formal change. We consider that a declaration recognising the crosssectoral and multilateral benefits of RTAs could, for practical purposes, be sufficient to give an indication to the negotiating parties as to the types of issues that should be taken into account in regional trade agreements, and that these considerations will duly be of influence on other WTO Members when considering these agreements, and, should this ever occur, on the WTO judicial branch in any decision on the compatibility of the agreement with Article XXIV GATT.

As noted, key concepts in the definition of a WTO compatible regional trade agreement are left vague in the legal texts. This creates an opportunity to implement the proposals advanced in this paper by means of a declaration that does not seek to 
introduce a discipline where there is currently none, but rather introduces as freestanding norms the factors emphasised in this paper. Such a declaration could, for example, state that:

WTO Members recognize the desirability of increasing freedom of trade by the development, through voluntary agreements, of closer integration between the economies of the parties to such agreements, taking into account the relative values of all economic sectors to these parties.

WTO Members recognize that the contribution to the expansion of world trade that may be made by closer integration between the economies of the parties to free trade agreements, customs unions and regional integration agreements is increased when such agreements have positive effects also on trade with WTO Members not party to such agreements.

The legal value of such a declaration is, admittedly, uncertain. However, it could set a framework for the political acceptability of the pro-development, pro-multilateral regional trade agreements for which this paper advocates. It also cannot be excluded that declarations of this type will have interpretive relevance in dispute settlement proceedings.

\section{Authoritative Interpretation}

A stronger, hybrid option could be an authoritative interpretation of Article XXIV GATT and Article V GATS under Article IX:2 of the Marrakesh Agreement, which could be crafted to account for both cross-sectoral trade-offs (by linking concessions in goods, services and possibly IP, as well as taking account of quasi-market access aspects such as Trade Facilitation) and the systemic and/or third party benefits of on-discriminatory reforms induced by RTAs.

\section{Supporting Multilateral Benefits: Binding RTA Disciplines}

In all three cases (full-scale reform, declaration or authoritative interpretation), we suggest that any multilateral benefits that are of real importance could be enhanced (and hence counted as more significant towards WTO compliance) by binding these benefits under Article II GATT. This is an unusual way to proceed, but it is legally possible, and has the great advantage that a single advantage can be legally protected without having to call into question the RTA as a whole under Article XXIV. Whether there is a practical need for such a suggestion is, of course, another matter.

It is worth underscoring that it is indeed technically possible - even though difficult - for RTA parties to legally guarantee (as opposed to just generate de facto) the multilateral benefits of the agreement. There is no legal reason why FTA rules cannot be bound under Article II GATT. Any commitment can be bound under these 
provisions so long as they do not undermine existing cross-cutting obligations. ${ }^{63}$ This would give third countries legal security with respect to any particular RTA commitment of interest to them.

Of course, third countries always have some legal security in the sense that they are already able to challenge the legality of a given RTA in WTO dispute settlement. But in reality this is something of a nuclear option, not only for the agreement at issue, but even for the WTO system. Claus-Dieter Ehlermann, former Appellate Body Chairman, wrote that decisions on the compatibility of Article XXIV were better addressed by the political organs than judicially. ${ }^{64}$

More importantly, currently challenges could of course only be negative (trying to attack preferences granted among parties to an RTA, thus re-establishing an MFN base line at best); if RTA parties were to bind all or some of their non-tariff commitments undertaken in the RTA (for instance specific commitments on trade facilitation) also in the WTO, Members would instead gain positive, economically valuable and enforceable rights, additional to those they had under the WTO prior to the RTA.

\section{North-South RTAs: "Exchange Rates" and the Notion of Graduation}

Returning to the starting point, we suggest that all the above approaches could and should integrate mechanisms of differentiated treatment in the case of North-South RTAs.

These would not be charity-based concessions to the weak, as Special and Differential Treatment is too often misunderstood, but rather adjustments in measurements (applied when assessing WTO compatibility) which serve to optimize the systemic outcome for the benefit of all, and as such form an organic part of the re-calibration proposed. To the extent that RTAs can make a contribution to the effective upgrading of trade, trade policy mechanisms, trade institutions, trade infrastructure etc. in SVEs, LDCs and others, this is likely to generate tangible benefits to all not only in the long but even in the medium and short term.

A logical approach would be to provide for differentiated "exchange rates" for LDCs, SVEs and/or developing countries generally for purposes of the (new) assessment of SAT, or the standard replacing it.

63 WTO 1990; WTO (1997), 1997, para 154. See, generally, Bartels and Häberli (2010).

${ }^{64}$ Ehlermann (2011), at 634. In this context, it makes sense to focus on smaller commitments that can be litigated, if necessary, without having to call into question the agreement as a whole. This has been done, in particular in Turkey - Textiles, where the panel and the Appellate Body were able to find that a particular set of quantitative restrictions violated WTO law without having to make any determinations on the legality of the agreement in the context of which they were adopted. Something similar occurred in Brazil - Tyres, where the Appellate Body by implication stated that a Mercosur ruling was inconsistent with WTO law, without having to make any determination on the WTO legality of Mercosur itself. 
These "exchange rates" could be based on and linked to economic data. This would allow for a somewhat organic application of a mechanism of graduation. ${ }^{65}$ Parties to North-South RTAs could thereby be asked to upgrade RTAs as and when the developing country party advances on the development ladder.

\section{Conclusions}

The EPA experience to date has provided practical input into what had been a largely theoretical debate on development, RTAs and the WTO. The difficulty the negotiators encountered in crafting a new pro-development/WTO-compatible RTA archetype, and the perverse outcomes that resulted from this two-sided task, illustrates the shortcomings of the current architecture of RTA disciplines within the WTO.

This paper has argued that rather than RTA parties' focusing their political and negotiating capital on tariff reduction, simply out of a reflexive obedience to prevailing interpretations of the "substantially all the trade" requirement of Article XXIV, the WTO system should encourage RTAs - particularly between North and South partners - that encourage a more holistic, value-chain approach. The authors argue that a wider view of measuring liberalization would allow greater flexibility for negotiators to focus limiting negotiating resources on areas of actual trade and development interest, and create potential benefits for the multilateral system by shifting the ambition of RTA partners into areas with non-discriminatory benefits. The authors argue that such an approach would be more consistent with the post1995 rationale for the WTO, and in line with emerging thinking on " $21^{\text {st }}$ Century" regionalism and - crucially - consistent with the original purpose of Article XXIV GATT, which was to allow for RTAs that maximise the benefits and minimise the detriments of regional trade liberalization.

The changes or adjustments proposed would require WTO Members and trade negotiators to overcome a fear of the unknown - a fear of making ambitious commitments in new and emerging areas where barriers and trade flows are difficult to quantify; where impact assessments may be difficult or not yet be possible; where cross-country databases are not yet fully developed; and where stakeholder interests are only vaguely understood. This fear is likely to be strongest in developing countries where trade databases are unreliable and/or non-existent, where coalitions and cross-Ministry bodies do not function as effective advocates for trade issues, and where political instability at home strongly limits the support provided to trade representatives overseas. However, these are challenges that must be met if future North-South regional trade agreements are to correspond to

${ }^{65}$ See generally Cottier (2006). 
the true economic interests not only of the parties to these agreements but also of other WTO members. 


\section{References}

Baldwin and Jaimovich (2010). "Are Free Trade Agreements Contagious?" CEPR Discussion Paper 7904.

Baldwin (2011). "21 st Century Regionalism: Filling the Gap Between 21 ${ }^{\text {st }}$ Century Trade and $20^{\text {th }}$ Century Trade Rules", Graduate Institute, Geneva, April 2011.

Bartels and Häberli (2010). "Binding Tariff Preference for Developing Countries under Article II GATT" (2010) 13 Journal of international Economic Law 969.

Bhagwati (2008). Termites in the Trading System, Oxford University Press, 2008.

Cottier (2006). 'From Progressive Liberalization to Progressive Regulation in WTO Law' (2006), 9 Journal of International Economic Law 779-821.

Crawford and Fiorentino (2005). "The Changing Landscape of Regional Trade Agreements". WTO Discussion Paper No. 8, World Trade Organisation, Geneva.

Dam (1963). 'Regional Economic Arrangements and the GATT: the Legacy of a Misconception' (1963) 30 University of Chicago Law Review 615.

Ehlermann (2011). 'Six Years on the Bench of the "World Trade Court": Some Personal Experiences as Member of the Appellate Body of the World Trade Organization' (2002) 26 Journal of World Trade 605.

Grossman and Helpman (1993). The Politics of Free Trade Agreements, NBER Working Paper No 4597, 1993.

Hilpold (2003). "Regional Integration According to Article XXIV GATT - Between Law and Politics." Max Planck Yearbook of United Nations Law, Vol 7, 2003.

Kemp and Wan (1976). 'An Elementary Proposition Concerning the Formation of Customs Unions' (1976) 6 Journal of International Economics 95-97.

Lang (2006). "Renegotiating Article XXIV - A Priority for African Countries Engaged in North-South Agreements". ATPC Work in Progress No. 33, Economic Commission for Africa, 2006.

Lipsey (1957). 'The Theory of Customs Unions: Trade Diversion and Welfare' (1957) 24 Economica 40-46.

McMillan (1993). 'Does Regional Integration Foster Open Trade? Economic Theory and GATT's Article XXIV'. In K. Anderson and R. Blackhurst, eds., Regional Integration and the Global Trading System, London, Harvester Wheatsheaf, 1993.

Mathis (2002). Regional Trade Agreements in the GATT/WTO: Article XXIV and the Internal Trade Requirement, TMC Asser, The Hague, 2002 
Matsushita (2004). "Legal Aspects of Free Trade Agreements: In the Context of Article XXIV of GATT 1994". In Matsushita and Ahn, eds, WTO and East Asia: New Perspectives, Cameron May Publishers, London 2004.

Meade (1955). The Theory of Customs Unions, North-Holland, Amsterdam, 1955.

Onguglo and Ito (2003). "How to Make EPAs WTO Compatible? Reforming the Rules on Regional Trade Agreements". ECDPM Discussion Paper No. 40, European Centre for Development Policy Management, Maastricht, July 2003.

Onguglo and Ito (2005). "In Defence of the ACP Submission on Special and Differential Treatment in Article XXIV". ECDPM Discussion Paper No. 67, European Centre for Development Policy Management, Maastricht, November 2005.

South Centre (2005). "Revisiting EPAs and WTO Compatibility". South Centre Analytical Note, Geneva, July 2005.

South Centre (2008). "Article XXIV and RTAs: How Much Wiggle Room for Developing Countries". South Centre Analytical Note, Geneva, December 2008.

Wilcox (1949). A Charter for World Trade, Macmillan, New York, 1949

World Bank (2006). Trade, Development and Doha - A Window Into the Issues. World Bank, Washington.

WTO (1990). GATT Panel Report, US - Sugar Headnote, L/6631, BISD 37S/228, 1990.

WTO (1997). EC - Bananas III, WT/DS27/AB/R, 1997.

WTO (1999). Turkey-Textiles, WT/DS34/AB/R, 1999.

WTO (2002). "Compendium of Issues Related to Regional Trade Agreements: Background Note by the Secretariat". Document Number TN/RL/W/8/Rev.1, World Trade Organization, Geneva, August 2002.

WTO (2004). "Submission on Regional Trade Agreements: Paper by the ACP Group of States". Document TN/RL/W/155, World Trade Organization, Geneva, April 2004

WTO (2011). World Trade Report 2011: The WTO and Preferential Trade Agreements: From Co-existence to Coherence, World Trade Organization, Geneva, 2011.

WTO (2012). World Trade Report 2012: Trade and Public Policies: A Closer Look at Non-Tariff Measures in the $21^{\text {st }}$ Century, World Trade Organization, Geneva, 2011. 


\section{Annex I. Proposals on Trade and Development RTAs}

\begin{tabular}{|c|c|}
\hline Author & Proposals / Relevant Text \\
\hline \multicolumn{2}{|l|}{ Submissions within the WTO } \\
\hline $\begin{array}{ll}\text { Jamaica } & (1999, \\
\text { WT/GC/W/369) }\end{array}$ & $\begin{array}{l}\text { Examine measurement of "substantially all the trade" (Article XXIV GATT) or have } \\
\text { "substantial sectoral coverage" (Article V GATS), in order to provide developing } \\
\text { countries with adequate scope for absorbing the adjustment costs of trade liberalization }\end{array}$ \\
\hline $\begin{array}{l}\text { ACP Group of States } \\
(2004, \mathrm{TN} / \mathrm{RL} / \mathrm{W} / 155)\end{array}$ & $\begin{array}{l}\text { - Flexibility for measuring "substantially all the trade" under Article XXIV } \\
\text { - Flexibility for measuring "other restrictive regulations of commerce" } \\
\text { - Transition periods beyond } 10 \text { years } \\
\text { - Clarification of notification and dispute settlement procedures } \\
\text { - Less onerous notification/transparency procedures }\end{array}$ \\
\hline $\begin{array}{l}\text { European Union }(2002 \text {, } \\
\text { TN/RL/W/14 } \\
\& 2005, \mathrm{TN} / \mathrm{RL} / \mathrm{W} 179)\end{array}$ & $\begin{array}{l}\text { S\&D flexibilities [that] "might be appropriate" include the length of the transitional } \\
\text { period, the level of final trade coverage and the degree of asymmetry in terms of } \\
\text { timetables for tariff reduction and elimination. }\end{array}$ \\
\hline $\begin{array}{ll}\text { Bolivia } & (2011, \\
\text { TN/RL/W/250) }\end{array}$ & $\begin{array}{l}\text { Special and differential treatment, in particular less than full reciprocity, shall be } \\
\text { provided to developing countries. }\end{array}$ \\
\hline China (TN/RL/W/185) & $\begin{array}{l}\text { Developing countries should "be subject to lower threshold and receive less than full } \\
\text { reciprocity treatment on the substantive requirements of RTA disciplines." }\end{array}$ \\
\hline \multicolumn{2}{|c|}{ Submissions outside the WTO } \\
\hline Onguglo and Ito (2003) & $\begin{array}{l}\text { - Lower/asymmetric liberalization thresholds \& product coverage } \\
\text { - Right of developing countries to apply safeguard measures \& use ORRCs as trade } \\
\text { remedies } \\
\text { - Ensure "sufficiently long" and asymmetric transition period, with transitory } \\
\text { measures protected from challenge } \\
\text { - More liberal rules of origin \& protect preferential rules from challenge } \\
\text { - Ensure that mutual recognition SPS/TBT standards are not deemed to constitute an } \\
\text { increased external barrier } \\
\text { - Ensure that developing country RTA member is not subject to excessive } \\
\text { compensation requirement } \\
\text { - Clarification of notification and dispute settlement procedures } \\
\text { Less onerous notification/transparency procedures }\end{array}$ \\
\hline $\begin{array}{l}\text { UN } \\
\text { Commission for Africa } \\
(2006)\end{array}$ & $\begin{array}{l}\text { - Liberalization levels should be defined as "exactly what products [developing } \\
\text { countries] need to exclude" } \\
\text { - Definitions of "other restrictive regulations of commerce" should not limit policy } \\
\text { space } \\
\text { - Transition periods beyond } 10 \text { years \& definition of "exceptional circumstances" } \\
\text { based on development concerns } \\
\text { - Less stringent notification/transparency procedures } \\
\text { Protection of Enabling Clause acquis }\end{array}$ \\
\hline South Centre (2008) & $\begin{array}{l}\text { - Increase flexibility of "substantially all the trade" percentages } \\
\text { - Insert S\&D language into Article XXIV } \\
\text { - Ensure flexible treatment for ORRCs } \\
\text { - 'Reasonable length of time' to be interpreted "in tandem with countries' } \\
\text { - development advancements } \\
\text { - } \text { - Dispute settlement to account for development aspects }\end{array}$ \\
\hline
\end{tabular}


